$$
\begin{aligned}
& \text { TX } 387 \\
& R 7 \\
& \text { Copy } 1
\end{aligned}
$$




\title{
THE WHOLESOMENESS OF OYSTERS AS FOOD
}

t

\author{
By Henry C. Rowe
}

President Connecticut Oyster- Growers' Association and New York and New England Oyster Shippers' Association, New Haven, Conn.

\section{*}

Paper presented before the Fourth International Fishery Congress held at Washington, U. S. A., September 22 to 26, 1908

BULLETIN OF THE BUREAU OF FISHERIES : : : : : : VOL. XXVIII, P. 259-267

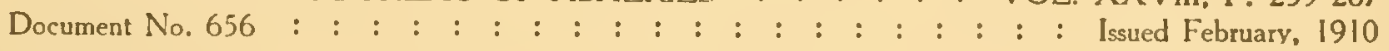





\title{
THE WHOLESOMENESS OF OYSTERS AS FOOD.
}

\author{
st \\ BY HENRY C. ROWE, \\ President Connecticut Oyster Growers' Association and New York and New England Oyster Shippers' \\ Association, New Haren, Conn. \\ $\%$
}

The necessity for the conservation of the resources of the nation has recently been brought emphatically before the public. The increase of our population in the past and its greater prospective increase emphasize the importance of not only conserving our resources but of encouraging the creation and development of productive industries. During the past thirty-five years such an industry has been created and developed in the propagation and growing of oysters. This industry produces already annually a great amount of valuable food, its yearly value in the states of Rhode Island, Connecticut, New York, New Jersey, Virginia, and California amounting to $\$ 9,316,252$. Other states are developing the industry, but these named have taken the lead. A large population is supported directly by it, and perhaps still more by contributory industries.

During the same period, while a large portion of our forests have been destroyed, the oyster farmers and cultivators have purchased from the different States permission to cultivate the hitherto barren ground covered by the waters of our bays and sounds to a depth of 25,50 , or even 100 feet, and have, by expensive and hazardous experiments, caused this unproductive ground to yield annualiy 10,235,566 bushels of oysters, a valuable and nutritious food, and furnished employment and livelihood to thousands.

While the United States and the various states have at public expense propagated millions of swimming fish, to be caught by those who are engaged in these fisheries, the oyster grower and planter has at his own cost propagated his own crops and worked out his own results by patient labor, costly experiments, and large investment. Instead of having his crops produced and protected for him, as has been done for the fishers of swimming fish, lie has paid large sums to the states for the use of the ground on which he might create and prosecute this industry. In Connecticut, for example, the oyster growers have paid to the state 
and towns over $\$ 260$, ooo for the franchises permitting them to cultivate oysters and in taxes upon these franclises, and have paid many hundreds of thousands more in taxes upon the steamers, shops, wharves, and other appurtenances of a great industry. In Rhode Island, besides the general benefit to the prosperity of the state resulting from a great productive industry - which is, of course, the principal consideration-the oyster growers pay annually to the state a very large sum in rentals for oyster grounds. The income to the state from this source in 1907 was $\$ 96,000$, and it is estimated that in 1908 it will be more than $\$$ Ioo, ooo.

The oyster industry has been created and developed notwithstanding many and great obstacles. Great storms have swept away the results of the outlay of millions of dollars in experiments and planting. The natural enemies of the oyster, especially the starfish and the drill, have destroyed millions of dollars worth of the product, and the oyster farmers have expended millions more in catching and destroying these enemies. They have suffered great losses from many causes and have encountered and defeated unnumbered difficulties, perils, and vicissitudes. Hostile legislation and litigation have been overcome. The lawless have sought to find flaws in the titles, so as to reap the fruits of the labor of others. Demagogues have appealed to the underlying anarchistic or poacher sentiment, which exists among some classes of voters.

One of the most trying experiences which the oyster grower has been called upon to meet is the recent storm of public notion in decrying oysters as an unwholesome food. People have been accustomed to regard oysters as a nutritious and especially as a digestible food, and one which is most welcome to the palate of the epicure. It is but natural that they should desire to know whether there is any foundation for the sensational assertions that have been made against oysters. In recent years many kinds of food, perhaps a majority of all the kinds, have been claimed to be objectionable in one way or another. They have been found adulterated, in insanitary environment, or exposed to contamination by the germs which are blown about in the dust of the streets. Milk has been found to be swarming with the bacilli of typhoid, diphtheria, and tuberculosis, and water with typhoid and malarial germs. These have caused hundreds of epidemics of typhoid fever and other diseases. Flies and mosquitoes have conveyed in multitudes of cases typhoid and malarial infection. Among them all probably no article of food has been attacked in so sensational a way, with so small reason or ascertained fact, as oysters. Some so-called scientific writers have attacked them because the subject was novel and sensational, although previous scientific research had proved the oyster to be a most nutritious, easily digested, and valuable food. A novelty is a welcome subject for a magazine or newspaper article. 
It has been claimed, perhaps truly, that there were formerly a few places where oysters were planted or floated that might be considered insanitary. While I bushel in I00,000 might be so situated, the other 99,999 are grown in the deep pure water of the great bays and sounds. In those cases where there was suspected danger of insanitary effects, or eren criticism, the great oystershipping firms voluntarily discontinued floating and shoring oysters, and the other shippers have been required by law to discontinue doing so. It is now forbidden to market any oysters from places that are not approved by the health authorities. But notwithstanding these facts, certain writers and reporters have continued to work this profitable vein of sensationalism. There was no definite statement that any typhoid fever germ had ever been found in an oyster, but there was a mass of insinuation and innuendo which wantonly injured a great industry.

It is contrary to public policy that a food such as oysters, which are noted for their great palatability, easiness of digestion, and high food value, should be lightly thrown aside without any evidence worthy of being called such. Every thoughtful man is compelled often to recognize the prevalence of popular errors. Many of the accepted theories and beliefs of twenty years ago have been disproved by facts later ascertained, and some were consigned to the scrap heap within a tenth part of that period. Among these subjects the theories of the causes of disease and how to avoid them are no exception, and have had a history of many radical changes, in which imagination and notion have by no means been absent. Hence reason dictates that we should be slow to accept theories, even of thinking men, until clearly proved, and far more, that our opinions ought not to be influenced in the least degree by the waves of popular notion which are promulgated by the sensational press to supply the morbid hunger of the unthinking multitude for novelty and excitement. The president of Columbia University has aptly said:

The daily press, with its hectic headlines and its guillotine-like opinions, assists us to form the habit of acting and judging without thinking. ****A distorted and inaccurate account of some important happening will serve to fix our permanent attitude toward a man or an event, and we may never know how hopelessly inadequate or erroneous the grounds for that attitude are.

Careful observation and examination lead to the conclusion that the recent attacks upon the healthfulness of oysters have little or no foundation in fact.

The most prominent case in which positive statements were made that typhoid fever was contracted through the use of oysters was published in a New Jersey newspaper within the past year and copied from that newspaper throughout much of the United States and Canada. These statements were thus placed before millions of readers. It was stated that two persons, 
Fierdinand Bendt and his wife, Rosa Bendt, of Newark, N. J., had died from typhoid fever, the result of eating infected oysters. On investigation it was found that the official report of the board of contagious diseases shows that neither of the persons had eaten oysters, but that they had eaten other foods which are sometimes infected by typhoid fever. Also the death certificates showed that one of them did not die of typhoid fever, but of cerebro-spinal fever.

Before the original article was printed, the attention of the reporter was called to the fact that the deceased had not eaten oysters, but he ignored the information and printed the sensational report regardless of truth. Later the newspaper was asked to correct the misstatement, and replied that a correction would be printed if the space required to do it was paid for.

In another case to which much prominence was given, a young physician gave to an evening paper an item in which it was stated that a certain young lady, a teacher in a public school, was very ill with a malignant case of typhoid, incurred by eating oysters. A careful investigation of the facts proved that she was but slightly ill, and not with typhoid fever; in fact, the doctor was unable to diagnose her case, but he half jestingly asked her one day if she had been eating oysters, and he was informed that the family had received some sent by a friend. He overlooked the fact, however, that she had not eaten any of them, while her mother and brother had done so and were not ill. A written statement signed by the mother and nurse of the patient established these facts. The result of the newspaper item was to give this young physician some free advertising, as having brought the young lady through a course of typhoid fever, and incidentally to instill an unfounded prejudice against oysters in the minds of thousands of readers of the newspaper.

Another illustration is afforded by the action of the health officers of Poquonnock, in Connecticut, where, several years ago, an epidemic of scarlet fever was attributed to the culture of oysters within the limits of the town. The health officers went so far as to require the destruction of the industry in their waters, for which the state of Connecticut some years later paid damages. At the present time no one believes that the oysters had anything to do with the epidemic which was then charged to them.

Many other instances can be cited in which sensational reports have been published with very little, if any, evidence underlying them. In many cases the motive for these reports is clearly that the reporter is paid for the "scoop," as he calls it, and it is an unfortunate fact that there are some newspapers that will accept and publish any sensation which is not actionable. Also it may possibly sometimes occur that a physician or health officer will carelessly allow himself to make public a suspicion or surmise which does great injustice, though it may perhaps enhance his own importance in the public eye. 
Then, too, there is an incentive to sensational reports about oysters, because the claim that they cause disease is a novelty. Milk has been found. to be the cause of typhoid fever in so many thousands of cases that such reports no longer secure so much attention in sensational journalism as does one alleged or suspected case that is attributed to oysters.

I would not be understood to say anything against the general and almost universal use of milk as a food. The most that we would claim is that care should be taken to keep milk free from contamination, but there is not onethousandth part as much evidence to cause us to fear the contamination of oysters witl disease germs as there is of milk; in fact, recently a great variety of foods have been declared dangerous to health. According to "The Jungle" and the investigations resulting, the methods under which meat was prepared for the market were revolting. Milk has been found to be swarming with the bacilli of tuberculosis, typhoid fever, and diphtheria. Flies have been proved to carry the germs of typhoid fever and other diseases, and deposit them upon every kind of food upon which they alight. Analysis has disclosed harmful adulterations in many of the prepared foods and drinks. Public and private supplies of drinking water have in many instances caused devastating epidemics of typhoid fever, and the bacilli have been found in vast quantities not only in the water but in milk which had come in contact with cans washed in the water.

Among these many dangers from food and drink, it becomes necessary to discriminate between those foods which are known to be dangerous to health and those to which mere suspicion is attached. We must eat and drink; therefore we need to know in what foods disease germs have actually been found, and, on the other hand, those to which unproved suspicion has attached.

To those who have read the sensational statements against oysters, it will be a surprise to know that although many expert bacteriologists have searched diligently for typlooid bacilli in oysters, I have not been able to learn of one single authenticated case in which bacilli have been found in oysters in the United States, except when placed there for purpose of experiment; while the germs have been found in milk and water in innumerable instances and are known to multipiy in these media to an extent beyond arithmetical expression and beyond the comprehension of human intelligence.

Another assertion that has been recklessly made about oysters concerns the use of preservatives. When oysters are handled as they are under modern methods - caught by steamers on one day, opened the next and, after being thoroughly chilled with ice, shipped into the country, there is not the slightest need or occasion for the use of chemical preservatives. I can say without hesitation that not an ounce of any preservative excepting ice has ever been used 
in oysters shipped by my firm during an experience of forty years, and I have no doubt that other reputable firms are equally particular. ' The fact that 99.9 per cent of the oysters now marketed are taken from deep salt water causes them to be incomparably more free from disease germs of all kinds than is true of most of our ordinary foods, which come in contact, while exposed for sale, with the air and dust of the streets, in which disease germs abound.

Hundreds of instances could be cited of the amazing multiplication of the typhoid-fever germ in drinking water, but one will suffice as an illustration: A few years ago there was a single case of typhoid fever in a house that was situated on a slope which led, a considerable distance away, to one of the water supplies of the city of New Haven. A little drainage proceeding from this house ran over the frozen ground of winter to the lake. There the germs multiplied to such stupendous extent as to communicate the disease to more than 500 of those who drank the water in that section of the city, with over 50 deaths.

The following statement from the Medical Journal gives a recent authority ("Milk and Its Relations to Public Health," Bulletin No. 4r, Hygienic Laboratory, Public Health and Marine-Hospital Service) upon the subject of milk, which is so generally and freely used, as follows:

The conviction that is forced upon the reader of these startling reports by men who are writing, not to cause a sensation but to state facts, is that the "jungle" as a disseminator of disease is as nothing compared with the dairy. The thought of eating meat prepared under the conditions that prevailed at one time in Chicago and that still prevail in other cities, whence emanated such pharasaical condemnation of the Chicago methods, may not be pleasant, but the actual danger to health from this cause is almost negligible when we consider the morbidity and the mortality directly traceable to milk from the ordinary farm or even from many a so-called model dairy. Dr. John W. Trank, of the Marine-Hospital Service, gives in this bulletin a tabulated report of 500 epidemics of typhoid fever, scarlet fever, and diphtheria caused by contaminated milk. These epidemics were only a few of those which have been reported and are accessible in the literature, and how many there may have been in the past which were never reported or the origin of which was never found can only be imagined. In addition to this, a report by Doctor Anderson shows the part which infected milk plays in the dissemination of tuberculosis. He examined 272 samples of the market milk of Washington, supplied by 104 dairies, and found that 6.72 per cent of the samples contained virulent tubercle bacilli, and of the dairies there were i per cent the milk from which contained these micro-organisms. One institution for children was found to be feeding its inmates on milk which caused tuberculosis in guinea pigs. Doctor Mahler's investigation led him to the conclusion that probably 25 per cent of the cows supplying milk to the District of Columbia are tuberculous.

Let us compare the preceding with the statement in the bulletin of the Chicago Board of Health, dated November 23, 1907, that the bacteriologists of the board of health of the city of Chicago examined samples of all the oysters shipped from the various sources to Chicago during the preceding month and found all of them absolutely free from any contamination or danger to health. 
In addition to the preceding comparison, no bacilli of tuberculosis, diphtheria, or any other disease have been found in oysters, and there has been no case, even of circumstantial evidence, showing that cooked oysters have caused typhoid fever, or any other disease, except possibly ptomaine poisoning, which may occur in any one of hundreds of foods if proper care is not exercised. It is conceded, however, that proper cooking will destroy bacilli in oysters if any do exist.

The limits of this paper forbid the introduction of a vast amount of available evidence along these lines, but it is clear that compared with the conclusive proof of the occasional danger in the use of milk and water, the evidence against the wholesomeness of oysters is so trifling as to be negligible. Let me repeat that I do not urge or imply the disuse of milk and water, but merely use a comparison with which we are all familiar, and I believe it is clear that so long as milk and water are freely and universally partaken of it is unreasonable to harbor the least prejudice against oysters as a food. 


